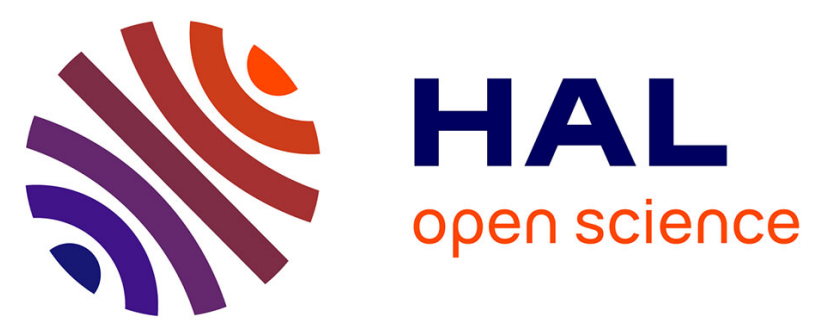

\title{
A sacrificial material approach for spark plasma sintering of complex shapes
}

Charles Manière, Lise Durand, Alicia Weibel, Geoffroy Chevallier, Claude

Estournès

\section{- To cite this version:}

Charles Manière, Lise Durand, Alicia Weibel, Geoffroy Chevallier, Claude Estournès. A sacrificial material approach for spark plasma sintering of complex shapes. Scripta Materialia, 2016, vol. 124, pp. 126-128. 10.1016/j.scriptamat.2016.07.006 . hal-01449277

\section{HAL Id: hal-01449277 \\ https://hal.science/hal-01449277}

Submitted on 30 Jan 2017

HAL is a multi-disciplinary open access archive for the deposit and dissemination of scientific research documents, whether they are published or not. The documents may come from teaching and research institutions in France or abroad, or from public or private research centers.
L'archive ouverte pluridisciplinaire HAL, est destinée au dépôt et à la diffusion de documents scientifiques de niveau recherche, publiés ou non, émanant des établissements d'enseignement et de recherche français ou étrangers, des laboratoires publics ou privés. 


\section{OATAO}

\section{Open Archive TOULOUSE Archive Ouverte (OATAO)}

OATAO is an open access repository that collects the work of Toulouse researchers and makes it freely available over the web where possible.

This is an author-deposited version published in: http://oatao.univ-toulouse.fr/ Eprints ID : 16745

To link to this article : DOI:10.1016/j.scriptamat.2016.07.006

URL : http://dx.doi.org/10.1016/j.scriptamat.2016.07.006

\section{To cite this version :}

Manière, Charles and Durand, Lise and Weibel, Alicia and Chevallier, Geoffroy and Estournès, Claude A sacrificial material approach for spark plasma sintering of complex shapes. (2016) Scripta Materialia, vol. 124. pp. 126-128. ISSN 1359-6462

Any correspondence concerning this service should be sent to the repository administrator: staff-oatao@listes-diff.inp-toulouse.fr 


\title{
A sacrificial material approach for spark plasma sintering of complex shapes
}

\author{
Charles Manière a,b ${ }^{\mathrm{a}}$, Lise Durand ${ }^{\mathrm{b}}$, Alicia Weibel ${ }^{\mathrm{a}}$, Geoffroy Chevallier ${ }^{\mathrm{a}}$, Claude Estournès ${ }^{\mathrm{a}, *}$ \\ a CIRIMAT, Université de Toulouse, CNRS, INPT, UPS, 118 Route de Narbonne, 31062 Toulouse cedex 9, France \\ ${ }^{\mathrm{b}}$ CEMES, CNRS UPR 8011 and Université de Toulouse, 29 rue Jeanne Marvig, 31055 Toulouse, France
}

Sacrificial material

\begin{abstract}
A B S T R A C T
An optimized process for the densification of a complex shape part is studied. Production of samples with a complex shape is very difficult in uniaxial die compaction processes because of the thickness differences responsible for densification inhomogeneities. To solve this problem in the case of a particular shape, we propose a solution consisting of homogenization of the shrinkage distances by means of the use of a sacrificial material. This solution was first studied by a finite element approach and then tested experimentally. We obtained a part of complex shape with an overall relative density of $99 \%$ and a homogeneous microstructure.
\end{abstract}

During the last decade the Spark Plasma Sintering technique (SPS) has been successfully used to densify a wide variety of materials $[1,2]$ (ceramics, metals and alloys, polymers and composites). This promising sintering technique is capable of producing highly dense materials with short processing time and microstructural control [3-5].

The main drawbacks of the technology are the control of the internal temperature of the die and the densification of the sample. The finite element simulation is often used to predict and adjust the SPS parameters to target these main objectives. In the literature, electro-thermal models are used to study the temperature distribution in the SPS column [6$10]$, the main difficulties are the identification and control of the electric and thermal contacts [11-17]. On the other hand, the powder densification can be calculated using mechanical models such as those proposed by Abouaf or Olevsky [18-21]. These models are identified by mechanical evaluations such as creep and compaction tests [22-24].

In a previous paper [21], we developed a method to identify the powder compaction parameters with simple SPS experiments. This method, based on Olevsky's model, was used to study the compaction of a $0.14 \mu \mathrm{m} \alpha$-alumina powder (alumina $99.99 \%$, reference TM-DAR, Taimei Chemicals Co. Ltd.). The compaction of a part with a complex shaped reported in Fig. 1a was performed by Electro-Thermo-Mechanical (ETM) simulation and by experimentation and both have shown strong inhomogeneities of densification using a classical configuration for the mold (Fig. 1b). This problem of densification may occur for complex shaped samples exhibiting large thickness differences. Indeed, in

\footnotetext{
* Corresponding author at: CE: CIRIMAT, 118 route de Narbonne, 31062 Toulouse, France.

E-mail address: estournes@chimie.ups-tlse.fr (C. Estournès).
}

uniaxial die compaction the maximum shrinkage distance is proportional to the thickness of the sample, thus small thicknesses have the lowest shrinkage distances. As a consequence, for samples like in the present case with two main thicknesses $h_{1}$ and $h_{2}$ (Fig. 1a, b), the densification of the area with the greater height $h_{2}$ is limited by the shrinkage of the area that is less high $h_{1}$. Therefore, the areas of low thickness (zone B in Fig. 1a) are dense while the areas of greater thickness (zone $\mathrm{H}$ in Fig. 1b) are not [21].

To avoid the problems of densification inhomogeneity, many solutions exist. The simplest approach is to machine a compacted simple geometry. The main drawback of this however is the cost. Moreover, for ceramics the machining is difficult as most are known to be fragile/brittle. Another solution is to use tools with two or more independent punches able to apply different pressures and displacements. This solution is used by many authors for hot pressing applications to densify shapes with large thickness differences [25-27]. The difficulty of this approach is to adapt the equipment to the shape to be formed. Another solution consists in using a die and punch configuration with punches of different heights [28]. Typically, the thicker zones of the sample have a higher punch height. This approach can be used to densify shapes with large thickness differences. However, the main difficulty is the great difference of pressure and the temperature gradient generated at the beginning of the SPS cycle when only the punches of the thicker areas are in contact.

The solution proposed in this paper, to densify the shape reported in Fig. 1a, consists of compacting two powder parts. One is the part to be formed and the other is a sacrificial ring of powder (Fig. 1c). The main role of the powder ring is to increase the shrinkage distance (when it densifies) of the thicker area of the part to be formed. This additional 
Desired geometry

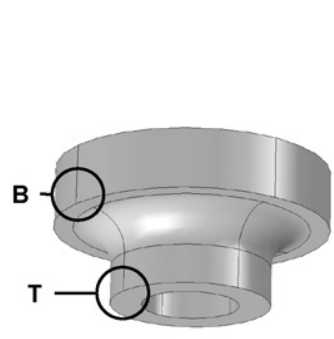

a)
Classical configuration

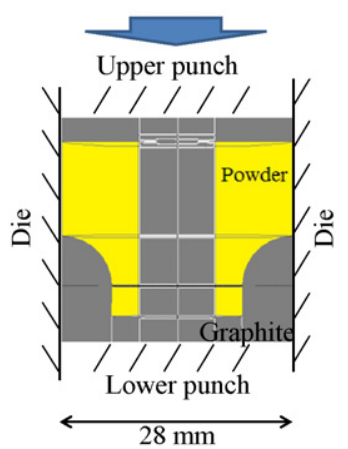

b)

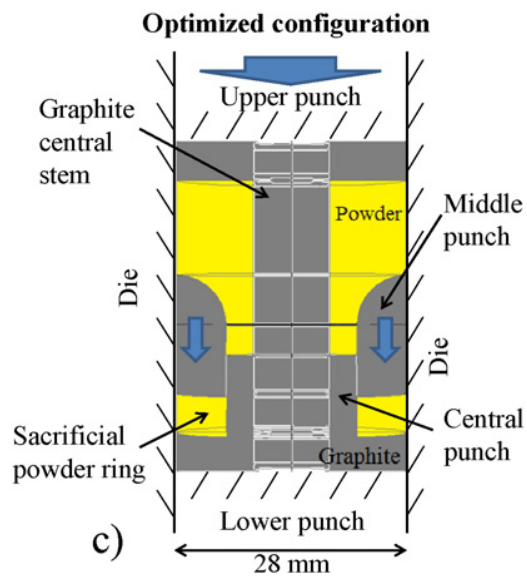

Fig. 1. Target sample geometry after compaction (a), classical SPS configuration (b) and the optimized SPS configuration with a sacrificial powder ring (c).

shrinkage distance finishes the densification of the previously nondense area (T zone Fig. 1a) in the classical configuration. With this approach, the pressure is distributed in both central and edge areas. In this study the powder in both parts is the same $0.14 \mu \mathrm{m} \alpha$-alumina. It is to be noted that the nature of the powder used for both the sacrificial ring and the complex shaped part is not necessarily the same, in theory; it is possible to use different powders as long as they have similar shrinkage curves.

The alumina powder compaction model used in our previous paper [21] is now applied to the new configuration (Fig. 1c). The simulation conditions are a $100 \mathrm{~K} / \mathrm{min}$ temperature ramp up to $1400{ }^{\circ} \mathrm{C}$ with a 5 min dwell and a constant applied pressure of $75 \mathrm{MPa}$. The temperature is considered homogeneous in all powder areas, the pressure is applied on the complex part upper face and the lower faces of the sacrificial ring have their displacement fixed. A no-penetration condition is introduced in all the lateral faces of both parts to prevent penetration of the powder into the mold/die tools which is not simulated. The displacement of the middle punch is modeled by a prescribed displacement. Using the ETM Model, trial-and-error optimization of the sacrificial ring height is performed up to full densification of the complex part. The result of the optimized configuration is reported in Fig. 2. The relative density field appears very homogeneous at the beginning and the end of the sintering cycle.

The experiment was performed on the SPS machine (Dr. Sinter 2080 SPS Syntex Inc., Japan) of the Plateforme Nationale CNRS de Frittage Flash located at the Université Toulouse III-Paul Sabatier. The thermal cycle applied was a $100 \mathrm{~K} / \mathrm{min}$ ramp up to $1400{ }^{\circ} \mathrm{C}$ without dwell (because the total densification was attained before $1400{ }^{\circ} \mathrm{C}$ ), a constant force of $18 \mathrm{kN}$ was applied. For easy removal of both samples, a graphite
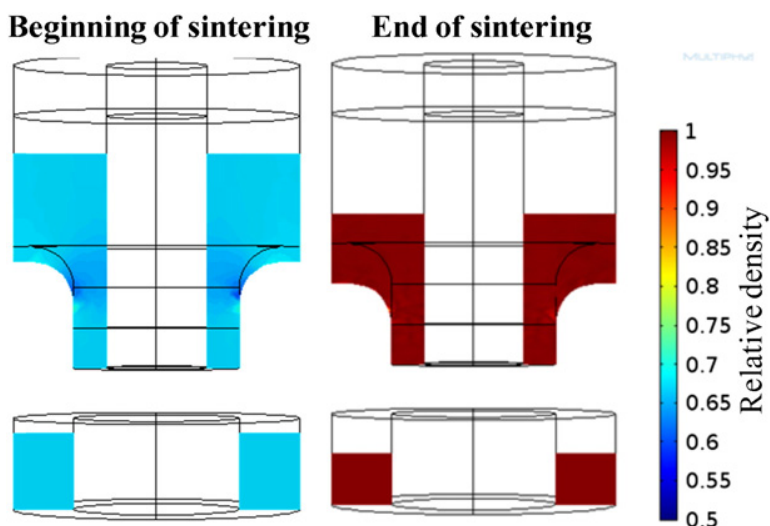

Fig. 2. Powder compaction simulation for the optimized configuration at the beginning and end of the sintering (the black lines correspond to the initial geometry). foil (papyex $®$ Mersen) was introduced in all the vertical and horizontal walls, and boron nitride spray was deposited on the rounded face of the middle punch (Fig. 1c). The same TM-DAR alumina powder as used in our previous paper [21] was used here for both the complex shaped part and the sacrificial ring (Fig. 1c). The initial relative density of the powder under pressure used in the simulation was 55\%. However, without pressure the initial relative density of the powder was lower than that value. Thus, to perform an experiment close to that of the simulation, it is essential to start from an initial relative density of roughly $55 \%$ in every area of the complex part (area B and T Fig. 1a). The cold compaction of the powder is performed first on the powder of the sacrificial ring, then on the $\mathrm{T}$ area of the part to be formed using a special central punch and finally in the B area (see Fig. 1a).

After SPS compaction, the complex part and the sacrificial ring are obtained very close to the desired shapes. Target complex shape heights h1 and h2 (Fig. 3) are respectively equal to 6.38 and $14.29 \mathrm{~mm}$. We obtained $\mathrm{h} 1$ and $\mathrm{h} 2$ equal respectively to 6.44 and $14.33 \mathrm{~mm}( \pm 0.05 \mathrm{~mm})$, the discrepancy between the heights was thus under $60 \mu \mathrm{m}$. The complex part was nearly fully dense with relative density, measured by Archimedes method, of 99\%. The fracture surfaces of the complex part in areas $\mathrm{T}$ and $\mathrm{B}$ were observed by field emission-gun scanning electron microscopy (FESEM, JEOL JSM 6700F) and are reported in Fig. 3. The area $\mathrm{T}$ that had a high level of porosity in the classical configuration is now almost fully densified, only few pores remain. Moreover, the microstructure of both areas $\mathrm{T}$ and $\mathrm{B}$ are similar with an average grain size of about $3 \mu \mathrm{m}$.

To conclude, we successfully sintered a complex shaped part with large thickness differences which presents full density and homogeneous microstructure. An approach with a sacrificial material is employed to homogenize the shrinkage distance in all areas of the complex part. In the present case, the sacrificial powder is the same as that used for the complex part but it is technically possible to use a different powder.

The main advantages of this approach are:

- The possibility of total densification of samples with very large thickness differences.

- A homogeneous distribution of the stress, because of the homogenization of shrinkage in all sample areas.

- Good control of the final sample shape, as in this technique the shape of the sample is imposed by the shapes of the die and punches and it is possible to accurately predict the height of the sintered shape by FEM simulation of the compaction.

The main disadvantages of this approach are:

- The material losses of the sacrificial part, although is possible to reduce the cost of this lost material using another cheaper material. 

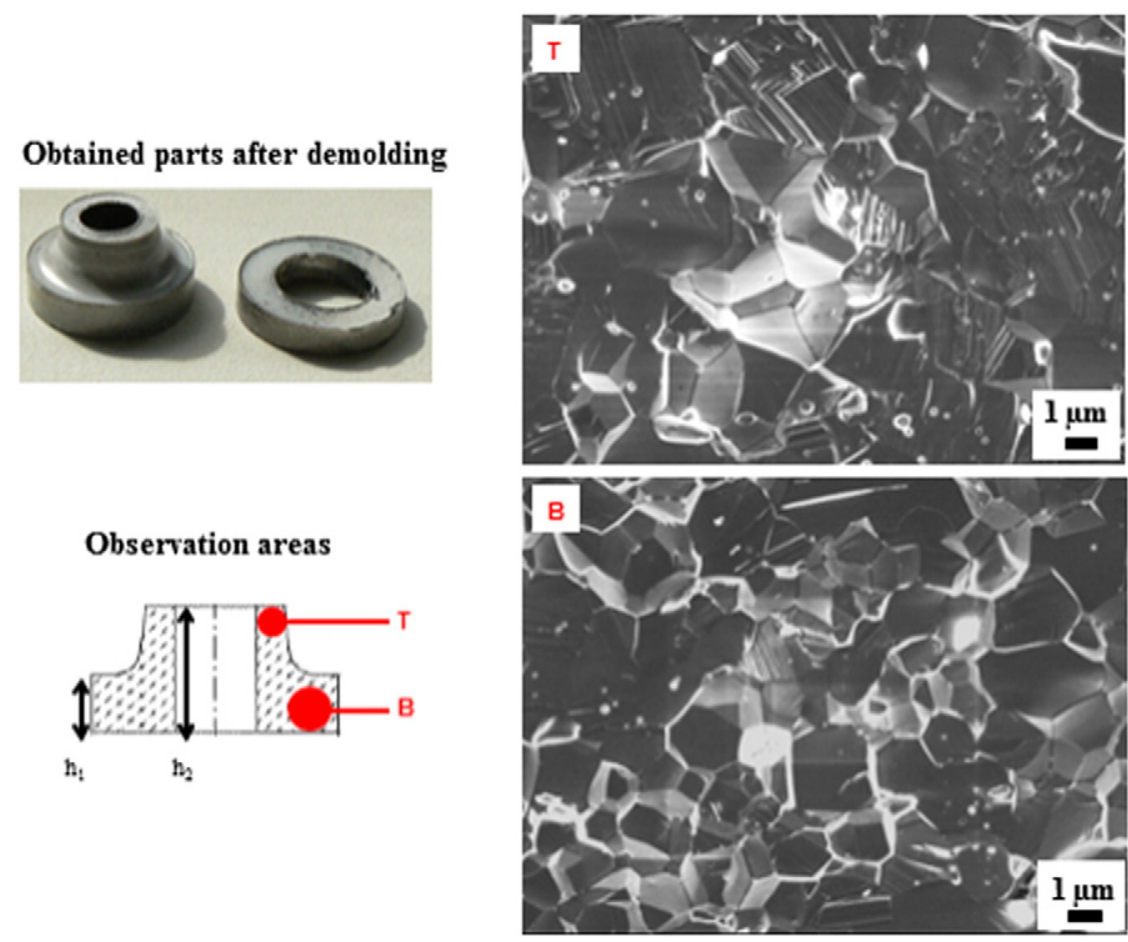

Fig. 3. Parts obtained immediately after demolding (upper left), SEM images of the fracture surfaces at points T and B (right).

- This approach is restrained to shapes with a limited number of thickness differences. In our case, even though there is a curved face, the overall shape consists of two main thicknesses. For shapes with a continuous variation or a large number of different thicknesses, the sacrificial material is too highly segmented and the present approach is too difficult to perform. For more complex shapes, another technique is required and will be detailed in a future work.

\section{Acknowledgments}

The support of the Plateforme Nationale CNRS de Frittage Flash (PNF2/CNRS) is gratefully appreciated. C.M. and C.E. thank the French National Research Agency (ANR) for financial support of this study within project ANR09 MAPR-007 Impulsé.

\section{References}

[1] S.H. Risbud, Y.-H. Han, Scr. Mater. 69 (2013) 105-106, http://dx.doi.org/10.1016/j. scriptamat.2013.02.024.

[2] R. Orrù, R. Licheri, A.M. Locci, A. Cincotti, G. Cao, Mater. Sci. Eng. R. Rep. 63 (2009) 127-287, http://dx.doi.org/10.1016/j.mser.2008.09.003.

[3] S. Grasso, Y. Sakka, G. Maizza, Sci. Technol. Adv. Mater. 10 (2009) 053001, http://dx. doi.org/10.1088/1468-6996/10/5/053001.

[4] O. Guillon, J. Gonzalez-Julian, B. Dargatz, T. Kessel, G. Schierning, J. Räthel, et al., Adv. Eng. Mater. 16 (2014) 830-849, http://dx.doi.org/10.1002/adem.201300409.

[5] B.-N. Kim, K. Hiraga, K. Morita, H. Yoshida, J. Eur. Ceram. Soc. 29 (2009) 323-327, http://dx.doi.org/10.1016/j.jeurceramsoc.2008.03.015.

[6] K. Matsugi, H. Kuramoto, T. Hatayama, O. Yanagisawa, J. Mater. Process. Technol. 134 (2003) 225-232, http://dx.doi.org/10.1016/s0924-0136(02)01039-7.

[7] G. Molénat, L. Durand, J. Galy, A. Couret, Journal of Metallurgy 2010 (2010) 1-9, http://dx.doi.org/10.1155/2010/145431.

[8] A. Pavia, L. Durand, F. Ajustron, V. Bley, G. Chevallier, A. Peigney, et al., J. Mater. Process. Technol. 213 (2013) 1327-1336, http://dx.doi.org/10.1016/j.jmatprotec.2013. 02.003.

[9] J.B. Allen, C. Walter, ISRN Mater. Sci. 2012 (2012) 1-9, http://dx.doi.org/10.5402/ 2012/698158.
[10] U. Anselmi-Tamburini, S. Gennari, J.E. Garay, Z.A. Munir, Mater. Sci. Eng. A 394 (2005) 139-148, http://dx.doi.org/10.1016/j.msea.2004.11.019.

[11] C. Manière, A. Pavia, L. Durand, G. Chevallier, K. Afanga, C. Estournès, J. Eur. Ceram. Soc. (2015)http://dx.doi.org/10.1016/j.jeurceramsoc.2015.10.033.

[12] C. Arnaud, C. Manière, G. Chevallier, C. Estournès, R. Mainguy, F. Lecouturier, et al., J. Mater. Sci. 50 (2015) 7364-7373, http://dx.doi.org/10.1007/s10853-015-9293-5.

[13] X. Wei, D. Giuntini, A.L. Maximenko, C.D. Haines, E.A. Olevsky, J. Am. Ceram. Soc. 98 (2015) 3553-3560, http://dx.doi.org/10.1111/jace.13621.

[14] C. Maniere, A. Pavia, L. Durand, G. Chevallier, V. Bley, K. Afanga, et al., Electr. Power Syst. Res. 127 (2015) 307-313, http://dx.doi.org/10.1016/j.epsr.2015.06.009.

[15] A. Zavaliangos, J. Zhang, M. Krammer, J.R. Groza, Mater. Sci. Eng. A 379 (2004) 218-228, http://dx.doi.org/10.1016/j.msea.2004.01.052.

[16] G. Maizza, S. Grasso, Y. Sakka, J. Mater. Sci. 44 (2009) 1219-1236, http://dx.doi.org/ 10.1007/s10853-008-3179-8.

[17] K. Vanmeensel, A. Laptev, O. Van der Biest, J. Vleugels, J. Eur. Ceram. Soc. 27 (2007) 979-985, http://dx.doi.org/10.1016/j.jeurceramsoc.2006.04.142.

[18] M. Abouaf, J.L. Chenot, G. Raisson, P. Bauduin, Int. J. Numer. Methods Eng. 25 (1988) $191-212$.

[19] E.A. Olevsky, Mater. Sci. Eng. R. Rep. 23 (1998) 41-100, http://dx.doi.org/10.1016 s0927-796x(98)00009-6.

[20] E.A. Olevsky, C. Garcia-Cardona, W.L. Bradbury, C.D. Haines, D.G. Martin, D. Kapoor, J. Am. Ceram. Soc. 95 (2012) 2414-2422, http://dx.doi.org/10.1111/j.1551-2916.2012. 05096.x.

[21] C. Manière, L. Durand, A. Weibel, C. Estournès, Acta Mater. 102 (2016) 169-175, http://dx.doi.org/10.1016/j.actamat.2015.09.003.

[22] M. Abouaf, PhD Thesis, Modelisation de la compaction de poudres métalliques frittées. Approche par la mécanique des milieux continus, Institut national polytechnique de Grenoble, 1985.

[23] C. Geindreau, D. Bouvard, P. Doremus, European Journal of Mechanics - A/Solids 18 (1999) 581-596, http://dx.doi.org/10.1016/s0997-7538(99)00102-3.

[24] C. Geindreau, D. Bouvard, P. Doremus, European Journal of Mechanics - A/Solids 18 (1999) 597-615, http://dx.doi.org/10.1016/s0997-7538(99)00101-1.

[25] H. Kim, O. Gilla, P. Dorémus, D. Bouvard, Int. J. Mech. Sci. 44 (2002) 2523-2539.

[26] A. Frachon, PhD Thesis, Modélisation et Simulation Numérique de la Compression en Matrice de Poudres Métalliques, Institut National Polytechnique de Grenoble, 2002.

[27] G.S. Wagle, PhD Thesis, Die Compaction Simulation: Simplifying the Application of a Complex Constitutive Model Using Numerical and Physical Experiments, The Pennsylvania State University, 2006.

[28] T. Voisin, PhD Thesis, Exploration of the SPS Route to Produce Turbine Blades for Aeronautical Applications: Development of an Efficient Tial Alloy and Densification of Near-net Shapes, Université Toulouse 3 Paul Sabatier, 2014. 